\title{
Bible reading insights from how the gospels and Acts link the apostles to Jesus: A biblical theological exploration
}

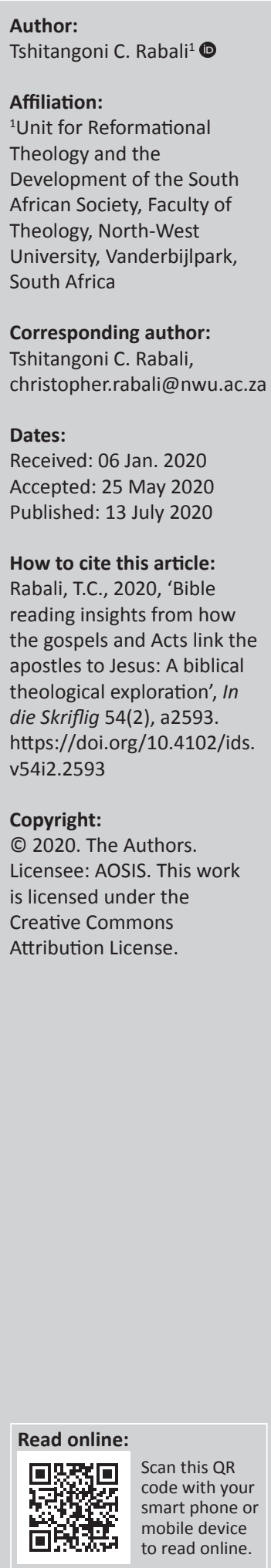

This article draws attention to reformed biblical theological insights derived from how the gospels and Acts relate the reading of the Scriptures by the apostles to Jesus. The presentation argues that the central concept in the teaching of Christ was a reading of the Scriptures that identifies him as the divine Saviour that the Old Testament speaks about, and that the gospels and Acts continue to promote such a reading of the Bible. The article is in the domain of biblical theology. The unique contribution of the article is that it highlights the biblical theological significance of recognising the close relationship that the gospels and Acts say exists between the teaching of the apostles by Jesus and their own witness in the early church for the reading of the Bible. The insights are also offered to illustrate the impact of reformed biblical theology on how to read the Bible.

Keywords: Jesus as teacher; New Testament theology; Bible interpretation; The gospels, LukeActs; Biblical theology; The apostles; The early church; New Testament canon.

\section{Introduction}

The four gospels confirm that Jesus did a lot of teaching (Mt 4:23; Mk 4:1; Lk 4:15; Jn 7:16, 28). The gospels devote most of their contents to the teaching of Jesus (Hagner 2012:110). A reading of the gospels shows that Jesus taught a variety of people: he taught individuals and crowds (Mt 5:1-2, 7:28-29, 19:16-22; Mk 4:1-8; Lk 7:40-47, 10:25-37; Jn 3:1-15, 4:7-26, 6:22-59); not only in synagogues (Mt 4:23; Mk 1:21; Lk 4:15; Jn 6:59), the temple (Mt 21:23; Mk 11:15, 17; Lk 19:47; Jn 7:14) and open spaces (Mt 5:1-2; Mk 6:31, 34; Lk 6:17, 18, 20; Jn 18:2), but also in private homes (Mt 9:10-13; Mk 14:3-9; Lk 14:1-24; Jn 12:1-11) and along the way (Mt 12:1-9a, 16:5-12; Mk 8:27-33; Lk 9:57-62; Jn 4:6-26) as he travelled throughout the areas he ministered (eds. Bimson et al. 1985:75; Craig 1965:123). The gospels also indicate that a large part of the teaching of Jesus was directed at his own disciples (Mt 10:5-42; Mk 7:17-23; Lk 11:1-13; Jn 13-16). Mark 4:34 tells us that Jesus made it a point that he explained further to them even the things he taught in public. Hagner (2012:111) helpfully notes that Jesus taught his apostles with the intention of making them the custodians of the accounts about his whole life. The disciples were to be his witnesses who also had the task of laying the foundation on which his church continues to be built (Ac 2:42; Eph 2:20). They were to teach others what Jesus taught them (Mt 28:19). In the process of turning the disciples into such custodians, Jesus did many signs before them but he appears to have also focused much of his attention on teaching them how to read the Scriptures. Jesus did this in both his pre-resurrection and post-resurrection teaching. What was the place and role of the Scriptures in the teaching of Jesus in general? What are some of the details that the gospels and Acts preserve to confirm that the way the apostles viewed and handled the Scriptures was to a large extent because of the teaching that Jesus gave them? This article discusses matters pertaining to these questions by looking at the gospels and Acts to highlight that the source of the reading of the Old Testament Scriptures in which Christ is recognised as the fulfilment thereof is Jesus, and that it occupied a critical and prominent role in both the teaching ministries of Jesus and his apostles. The article then argues that reformed biblical theology has to be appreciated not only as the fruit of such a reading of the Bible but also as embodying presuppositions that enhance a reading of the Scriptures which follows Christ and his apostles.

The article aims to achieve its goal by (1) explaining its methodological approach; (2) exploring what New Testament scholars say about the portrait of Jesus as teacher in the gospels; (3) summing up what others have observed about the place of the Scriptures in the teaching of Jesus; (4) drawing attention to some important ways in which Jesus used the Scriptures in his self-disclosure; (5) discussing how Jesus transformed the way that his disciples read the Scriptures; (6) presenting 
indications from Acts to show that the apostles focused their teaching on Jesus as being the Saviour that the Old Testament promised; (7) indicating how reformed biblical theology relate to the reading of the Bible that the gospels and Acts are advancing and (8) offering some concluding remarks.

\section{Methodological issues that inform the article}

The approach followed in this article is primarily informed by what the gospels and Acts say about themselves or their self-witness. In this case, the gospels and Acts present themselves as historical narratives and are recognised as such by many scholars (Boda 2017:127; Hagner 2012:61; Kaiser \& Silva 2007:123). This article also follows many scholars in approaching the gospels and Acts as being part of the great biblical narrative that begins with Genesis and ends with Revelation (Boda 2012:135; Kaiser \& Silva 2007:69; Provan 2012:275). This also flows from their being part of the one Bible.

The article further approaches the gospels and Acts as being both historical and theological. This is also something that is generally affirmed by many (Kaiser \& Silva 2007:157, 161; Longman III 2012:120). This article accordingly views the contents of the gospels and Acts as concerning things that took place whilst also recognising that they are part of books that are telling the story with an agenda or certain purposes. The gospels and Acts are transparent about the fact that they are communicating a particular message and that selection of material was involved in their composition (Lk 1:1-4; Jn 20:30-31; Ac 1:1-2).

What is stated above implies that it is possible to identify a particular theological theme or an aspect of the message and explore its significance in terms of how it fits into the total message of this part of the Bible as well as how it relates to the rest of the Bible. In the use of comments from literature about specific Bible passages, due regard was therefore taken to make sure that those sources have adequately taken into consideration their immediate contexts, comparing them with their parallels when such exist, and how they also place them within the context of Old Testament teaching as well as that of the rest of the New Testament. Smuts (2013:xxii) helpfully refers to this as a downward-sideways-backwardforward reading of such passages. It is also the method that is commonly associated with biblical theology (Beale 2011:9; Johnson 2007:7; Keller 2015:47, 48).

\section{The portrait of Jesus as teacher looms large in the gospels}

The prominence of preaching and teaching in the ministry of Jesus according to the gospels indicates that the portrait of Jesus as 'a teacher' or 'prophet' is one of the most important that we have to use when attempting to comprehend his role on earth. It is true that the title 'teacher' or 'prophet' is in the gospels one that Jesus sparingly used to refer to himself (Cullmann 1963:30). In his survey of the Christological titles that are found in the gospel of Matthew, Viljoen (2011:12) also confirms that there are very few instances in which the title 'teacher' is used by Jesus to refer to himself. The point, however, is that when one looks beyond the titles that Jesus and his followers use to refer to him, one finds the gospels constantly pointing to the work that Jesus did to reveal, teach and preach. Mark 1:37-38, for instance, introduces the preaching tour of Jesus in Galilee by words that suggests that Jesus wanted his disciples to understand that teaching and preaching was an integral part of his mission when he said to them, 'Let us go somewhere else - to the nearby villages - so I can preach there also. That is why I have come'. Commentators observe that this passage draws attention to the priority of preaching in the ministry of Jesus (Boring 2006:69; Hendriksen 1975:73; Stein 2008:102).

The portrait of Jesus as 'teacher' in the gospels is therefore inescapable. The gospels make it clear that the titles that Jesus and his disciples use for him in the gospels must be understood in such a way that they incorporate a multiplicity of roles, and that the various functions have to include that of a 'teacher' to form a balanced understanding of his identity and work.

What the gospels say about the role of Jesus in teaching and preaching prompted scholars to use many figures associated with Old Testament encouraged hopes to understand and explain his identity. Schreiner (2008:173-179) briefly surveys the three figures of Jesus as the New Moses, and Jesus as True Wisdom and Jesus as a Prophet. We note that these three somehow also parallel the three broad categories into which the Old Testament books are classified. These are the Law of Moses, the Writings (including the Psalms) and the Prophets (Dempster 2012:167; VanDerKam 2001:213).

Regarding Jesus as the New Moses, Schreiner finds many allusions that support such a conception of Jesus. He also refers to Deuteronomy 18:15-22 as the basis of the conception (Schreiner 2008:174). Schreiner (2008:175) then concludes his survey in this regard by saying that the conception helps to indicate that all of God's promises are fulfilled in Jesus, and that the prophet predicted by Moses is none other than him.

Schreiner $(2008: 175,176)$ also discusses the role of Jesus as true Wisdom and then points out that it serves to indicate that those who come to Jesus or who positively respond to his invitation find rest, life and wisdom. He points out that according to passages such as Matthew (12:41-42) and Luke (11:31-32), Jesus offered wisdom far greater than even Solomon (Schreiner 2008:177).

The conception of Jesus as a Prophet is also one that Schreiner $(2008: 177,178,179)$ finds many allusions for in the gospels. He helpfully indicates that it draws attention to the authority of Jesus as God's final prophet, who in the parable of the vineyard (Mt 21:33-44 par.) is the son of the vineyard owner.

It is therefore clear that the gospels are, in this regard, indicating that in his work as 'Teacher', Jesus was not only 
bringing God's revelation in the Law of Moses, the Writings and the Prophets to a climax, but he was also showing his close association with it as the one who fulfilled it, and also as the one who was the embodiment of what that revelation as a whole was about. He was in terms of John's gospel 'the truth' (Jn 1:17, 14:6). It is important to also explore what the gospels say about the place of the Scriptures in his teaching ministry.

\section{The prominence of the Scriptures in the teaching ministry of Jesus Christ}

The gospels show that the Scriptures occupied a central place in the ministry of Jesus. The so-called fulfilment sayings in Matthew make this point (Schreiner 2008:170). Jesus did not only fulfil the Scriptures of the Old Testament in his life and works generally. He also did it in his use of the Old Testament Scriptures. Dever (2005:46) notes this prominence of the Word of God in Matthew (4:14, 8:17, 12:17). Jesus did not therefore take people away from the Scriptures but actually brought them closer to them. In Matthew 5:17, Jesus actually claimed to have fulfilled 'the law and the prophets'. Dever (2005:46) then points out that 'in Matthews, Jesus presents himself as the key to understanding the Old Testament Scriptures'. The business of Jesus during his earthly ministry included that of teaching this matter. The gospels are therefore saying that Jesus explained his identity to people at large and to his disciples by means of the Old Testament Scriptures.

This means that the ministry of Jesus was according to the gospels one that involved a widespread usage of the Scriptures. Reymond $(2008: 159,160,161)$ aptly indicates that Jesus also appealed to the Scriptures and considered them as reliable, inspired of God and authoritative. It is important to point out here that Jesus also used the Scriptures in controversies between him and the Jewish leaders of his times (Mt 9:10-13; Mk 10:2-9; Lk 20:41-44; Jn 10:31-39). In some of the controversies, he introduced his references to the Scriptures by the phrase, 'have you never read' (Mt 12:3, 21:16; Mk:12:10) - a mode of speaking that not only made the audience think, but also suggests that he was at the same time dealing with a possible neglect of certain parts of the Scriptures amongst his audience. Reymond (2008:159, 160) also draws attention to several instances which show that Jesus viewed the history that is presented in the Old Testament 'as unimpeachable'. This matter concerns the historicity of the Old Testament. Longman III (2012:99) aptly draws attention to the fact that those that reject the historical nature of the Old Testament are by implication unable to maintain the historical trustworthiness of the New Testament. Part of the reason why this is the case is because such a stance would be contrary to the attitude that the gospels ascribe to Jesus regarding the matter, and the rest of the New Testament happens to follow his attitude. DeYoung (2014:32) briefly but aptly discusses this matter and then states that from its very beginning, Christianity like the Jewish faith from whose bosom it arose made historical claims.
The gospels also refer to instances when those that listened to Jesus were amazed by the difference between his teaching and that of their scribes (Mt 7:28-29; Mk 1:21-22; Lk 4:22; Jn 7:45-46). Kaiser and Silva (2007:167f) and Hagner (2012:110) point out that the difference was not only in style but also primarily in something to do with the content of the teaching of Jesus. It is important to recognise here that the gospels also indicate that this matter was often part of the reason why the Jewish leaders accused him of blasphemy (Jn 10:33; Mk 2:7). The accusation reached its climax when the Jewish council found Jesus guilty of blasphemy (Mt 26:65; Mk 14:63-64; Lk 22:70-71). The point we are making here is that this is a crucial matter that the gospels are emphasising about how Jesus read the Scriptures. The matter is also apparent in what the gospels say on how Jesus used the Scriptures in his self-disclosure.

\section{The Scriptures in the self-disclosure of Jesus}

\section{Jesus makes himself known by affirming the testimony of John the Baptist}

The gospels indicate that John the Baptist prepared the way for Jesus by announcing that the one that the people were made to await by the Old Testament promises was about to arrive amongst them (Mt 3:1-3; Mk 1:1-3; Lk 3:1-6; Jn 1:6-8, 19-23). It is significant that all the gospels tell us that John the Baptist explained his relationship to that long awaited one in terms of the Old Testament Scriptures. Hagner (2012:70-71) notes this and then helpfully observes that 'John the Baptist becomes a pivotal turning point between promise and fulfilment'. John the Baptist had a popular ministry. The Jewish leaders in Jerusalem even dispatched a team of priests and Levites to ask him who he was (Jn 1:19). John responded by primarily describing himself as the special messenger that God promised to send just ahead of the long awaited one in terms of passages like Isaiah 40:3 (Card 2014:38; Heil 2015:17; Morris 1971:137). This served to place such passages in the public limelight amongst the people and their leaders. Jesus made himself known in terms of the same passages by relating himself to the testimony that John the Baptist gave concerning him. This was a powerful way of using the Scriptures in his self-disclosure as it involved doing so by means of passages that John the Baptist had recently made popular. Matthew 21:23-27 and its parallels show that Christ responded to the question that the Jewish leaders later asked him concerning his authority by utilising this way of making himself known. Jesus virtually does the same in John 5:33 when he states that John the Baptist had witnessed about the truth (Morris 1971:326; Selvaggio 2010:58).

\section{Jesus used Isaiah 61:1-2 as he made himself known at Nazareth}

Luke 4:14-21 indicates that Jesus also made himself known through Isaiah 61:1-2. Luke 4:21 tells us that after reading the passage, Jesus began his teaching by saying that 'today this scripture is fulfilled in your hearing'. Jesus thereby made 
himself known as the one that was anointed to proclaim the good news hinted to in Isaiah 61:1-2 (Carroll 2012:113; Geldenhuys 1977:168).

\section{Jesus makes himself known by employing Old Testament designations}

Jesus also disclosed his divine identity by applying to himself Old Testament-based designations that are associated with God and his actions. The gospel of John shows this by featuring many of his I AM sayings (Hagner 2012:279). One of the most common designations that Jesus employs in the gospels is 'Son of Man'. Schreiner (2008:213-232) carefully surveys the various views that scholars hold about its background as well as what Jesus conveyed by using it. He concludes by locating the primary background for its use in the gospels as traceable back to Daniel 7. Schreiner (2008) then also helpfully writes that:

Jesus uses the term to refer to his ministry on earth, his suffering, and his glorification in the future. Even the sayings about suffering anticipate glorification, for they promise a future resurrection. (p. 232)

The constant use of the designation by Jesus for himself in the gospels is taken here as part of his self-disclosure by the Scriptures that are linked to an Old Testament eschatological passage (Waltke 2008:85). Beale (2011:189) associates the Daniel 7 Son of Man with the end time Adam, who unlike the first Adam overcomes the forces of evil and gains glory for himself and his people.

\section{Jesus often explicitly claimed that the entire Old Testament in all its parts is about him}

The use of the Scriptures in the self-disclosure of Jesus must also be seen where he referred to them as a whole in his ministry. He approached all of the Old Testament as integrated, and as something that is about him. Gaffin (2008:66) draws attention to the importance of this. It had to do with the understanding that Jesus had of himself as being the fulfilment of all that is written in Scripture. An example of this usage in the self-disclosure of Jesus is Luke 18:31-33. Jesus continued with this usage in his post-resurrection teaching to the disciples according to Luke 24:25-27, 44 .

\section{Jesus transformed the way in which his apostles read the Scriptures}

The gospels are indicating that the promise of Jesus to make the disciples fishers of human eventually became true. The disciples were to play a significant role in the future of what Jesus had come to do. Bauckham (2006:95) helpfully suggests that the 12 had to be qualified for the mission of continuing 'the mission of Jesus'. The process, which amounts to a great transformation, also involved how they read the Scriptures.

The teaching that Jesus gave to his apostles was a critical means to achieve their transformation in this regard. The gospels show that Jesus gave them special teachings over and above what they learned by being always around him. Mark 9:30-31a even reports an occasion in which the primary motivation for Jesus to not disclose his whereabouts was his need of time to teach them. Many commentators share this observation (Boring 2006:276; Stein 2008:439).

His life and signs contributed as well. John 2:11 accordingly draws attention to this when it reports that with the changing of water into wine, they saw his glory and 'believed in him' (Selvaggio 2010:22). They learned from his allusions to the Old Testament whenever he presented himself as the antitype of institutions, persons, events and even services associated with the Old Testament (Johnson 2007:118; Kaiser \& Silva 2007:103, 104).

Mention must also be made of the love, grace and patience that Jesus had to exercise towards the disciples. The gospels show many instances in which they misunderstood him and in certain cases had to be corrected. Hagner (2012:179) mentions some of the weaknesses of the disciples that are reported in Mark. The disciples found it difficult to grasp that the humiliation and sufferings that Jesus was going through were what he had to endure as the Messiah in terms of the Scriptures. The gospels indicate that Jesus had to repeatedly teach them about the matter. Peter even had the audacity to 'rebuke' Jesus when he taught them about it even after he had confessed that Jesus was the Christ (Mk 8:32).

The death and resurrection of Jesus as well as his ascension and coming of the Spirit were events that were pivotal to help complete their learning process in this regard. John 16:12-15 shows that Jesus was aware that the understanding of the disciples was to achieve the required level or depth only after these redemptive events had also taken place. This is a matter that had to do with progression in redemptive acts and the accompanying revelation (Hendriksen 1973:327-328). This implies that before the resurrection of Jesus, it was difficult for the disciples to properly connect all the dots to Jesus even though those linkages were there in the Scriptures. Boda (2017) alludes to this when he expresses himself as follows:

[S]ince Jesus inaugurates the age that brings redemption and revelation to its climax, any OT redemptive act or revelatory insight will contribute toward and/or receive greater clarity in and through Jesus Christ and the Holy Spirit. (p. 174)

The post-resurrection teaching of Jesus was accordingly essential and critical to ensure that their transformation was complete. It is clear in the gospels that when Jesus met with the disciples after his resurrection, he primarily taught them. This post-resurrection teaching of Jesus did refer to what he taught them before his crucifixion on the hand of the Scriptures. Luke 24 therefore shows Christ doing this to two of his disciples who were going to Emmaus (Lloyd-Jones 2013:80). Gaffin (2008:65) correctly points out that Luke 24:44-47 is referring to the teaching activity that Jesus gave over the 40 day period that is mentioned in Acts 1:3. Gaffin (2008) then helpfully states that the 40 day period: 
[W] as marked largely by instruction in which the resurrected Christ, having triumphed over death by his labors and found rest from his sufferings, now, from that vintage point, discloses and explains to his disciples the significance of his sufferings and consequent glory. (p. 65)

Jesus is said to have done this by means of the Scriptures. The things he taught before now made far greater sense to them after his resurrection.

\section{Indications in Acts that the teaching of the apostles focused on teaching that Jesus was the Saviour that the Scriptures promised}

It is apparent that Acts was intended to be read together with the gospel of Luke. Both were written by Luke (Schreiner 2008:289). Acts 1:1-5 encourages such a view by the way it refers to Luke. Hill (2008:237) aptly describes this relationship when he writes that Acts is the continuation of what Jesus did and taught, but now through 'the apostles whom he had chosen'. Acts presupposes the contents of Luke (Hagner 2012:307). The scope of that continuation extends to what Jesus taught them about the reading of the Scriptures.

Acts is accordingly viewed here as a powerful narrative that tells us that the ministry and victory of Christ was not in vain; the apostles were able to lay the foundation of a growing worldwide church as Jesus commissioned them. It is a narrative that, amongst others, is saying that what God promised, in the Old Testament and confirmed in the teaching of Christ, happened through the foundation laying witness of his apostles. Hagner (2012:310) accordingly points out that the fulfilment of Scripture is an important theme in Acts. That the theme of fulfilment of the Scriptures in Christ was at the core of the gospel proclamation by the apostles in Acts is to be viewed as because of the ministry of Jesus. Many passages and cases in Acts point in this direction. Some of these are featured in this section of the article.

\section{The way in which Peter speaks of Jesus in Acts 2}

Acts 2:14-16 explains the context of the proclamation by Peter on the day of Pentecost. People had just heard the disciples declare the wonders of God in their languages (Ac 2:11) and were asking about the meaning of it (Ac 2:12). Peter's explanation then refers to the promise of the Spirit in Joel 2:28-32 to show that the events signal the inauguration of the last days (Bock 2007:137), but then connects it to the death and resurrection and ascension of Jesus by referring to Psalms 16 and 110 in Acts 2:17-36. Peter drives home the point that Jesus having been raised from death by God and now exalted 'to the right hand of God, he has received from the Father the promised Holy Spirit and has poured what you now see and hear' (Ac 2:32-33). There is explicit indication in Acts 1:4 that part of the post-resurrection teaching by Jesus was that they 'wait for the gift my Father promised, which you have heard me speak about'. In the course of handling the Scriptures that Peter refers to in his Acts 2 sermon, he also talks about the sufferings and death of Jesus as matters that were in God's plan and foreknowledge (Ac 2:23). This was the very matter that Peter and his fellow disciples struggled to understand when Christ repeatedly taught them prior to his resurrection. Peter's sermon on Pentecost therefore contains indications that the disciples were now reading the Scriptures the way Jesus taught them, a reading wherein Christ is the focus of the Scriptures.

\section{How Peter preached Jesus in Acts 3}

Acts 3:12-26 is a report about what Peter preached in the temple. It was after the healing of a lame person (Ac 3:1-11). There are important references and allusions to the Scriptures (Donnelly 2005:65). Bock (2007:165) aptly sums up the essence of the references when he, commenting on this speech, says that it is 'one of the most christologically rich addresses in Acts as Jesus is the Servant, the Holy and Righteous One, the Author of life, the Prophet like Moses, the Christ, and the Seed of Abraham'. It must be noted that Peter hints to these titles and roles of Jesus by general references to Scriptures as when he says 'all the prophets' in Acts 3:18 and 24, and also by references and allusions to specific passages like Deuteronomy 18:15-19 in Acts 3:22-23. Acts is thereby indicating that the apostles read the Scriptures the way Jesus taught them.

\section{The speech Peter made at his and John's trial by the Sanhedrin in Acts 4}

Acts 4:8-12 preserves words that Peter uttered when he and John were being tried by the Sanhedrin (Hughes 2014:61, 62). It was an opportunity for them to witness about Jesus. They did so by referring to Psalm 118 when they said that Jesus is 'the stone you builders rejected, which has become the cornerstone'. Jesus had also used the same passage in the same way during one of his encounters with the Sanhedrin according to Mark 12:10-11 and its parallels. In Acts 4:12, Peter and John then also made the point that salvation is found in no one else but Jesus alone. Acts 4:13c then points out that the Jewish council took note that Peter and John 'had been with Jesus', a phrase that implies that their reading of the Scriptures was because of the influence of Jesus. Bock (2007:196) suggests that their training was viewed as having been outside the official circle.

\section{The reading of the Bible that is apparent in the prayer of Acts 4:24-30}

Acts 4:24-30 reports the prayer the church used following the threats that the Sanhedrin made to Peter and John. Our interest is in what the prayer shows about how the church was reading the Scriptures. The prayer uses Psalm 2:1-2, and applies it to the rejection of Jesus and also confesses that rejection as foreknown and foretold by God (Bock 2007:208). Jesus is explicitly referred to as God's holy servant; one anointed by God (Ac 4:27); a reading of Psalm 2 that indicates that the church was reading the Bible as Jesus taught his disciples. 


\section{Other cases indicating the same way of reading the Bible in Acts}

There are many other such cases in Acts. Many scholars note this reality (Carson 2008:127; Donnelly 2005:68; Swindoll 2016:117). Carson (2008:127) indicates that the apostles tried to convince their fellow Jews from the Scriptures whilst believing that their former reading of it 'was wrong, or at least incomplete, and their current reading is right'. The majority of the Jewish leaders continued rejecting them and their message, and Acts brings its report about this division to a climax when it narrates the response of the leaders of the Jewish community in Rome to Paul and his message in Acts 28:17-29.

\section{Reformed biblical theology and the reading of the Bible}

The gospels and Acts are not the only books that preserve what Jesus entrusted to his apostles when he opened their minds to understand the Scriptures (Lk 24:45). Their total witness about Jesus and his unique place in the Scriptures ultimately found its full expression in all the books that were written as part of their ministry in the early church; the books which together form the New Testament (Ridderbos 1978:21; Hill 2008:253).

The early church therefore started reading the Old Testament Scriptures together with the books of the New Testament which were written to preserve the witness of the apostles to Jesus. Following Jesus and his apostles meant that all the books of both the Old and New Testaments are united by Jesus, and were as such read together; Jesus as the focus of their message (Johnson 2007:163).

The oneness that the apostles established between their witness, which is through the Scriptures of the New Testament and the Old Testament Scriptures, was so strong that it could not be destroyed by the Jewish persecutions in the early decades of the first century; it survived the destruction of the Jewish temple around $70 \mathrm{AD}$ as well as several waves of persecutions by the Roman Empire; and even withstood threats from within the churches when false teachers who did not appreciate it arose in the 2nd century (Trueman 2012:83). The threats helped to push the churches of the 2nd century to make formal pronouncements about this oneness and thereby hastened the process that confirmed their status in the Christian canon as we have it today (Cairns 1981:118; Trueman 2012:83). The principle of apostolicity played a critical role in that process (Cairns 1981:118; Sproul 2005:47, 48). The doctrinal challenges that the church had later to resolve in the ecumenical councils from the 4th century onwards solidified this oneness as appeal to both the two Testaments was made (Cairns 1981:131; Trueman 2012:104). Catechetical, and Liturgical as well as Confessional materials associated with the life and witness of the early church also strengthened the same oneness as many of it affirmed that the Old and New Testaments belong together also in the way that these two parts of the Scriptures were utilised in such tools.

The 16th century reformation rediscovered the Bible and emphasised the way its two parts are to be used together. The 16th century reformers were often quick to point out that what they were maintaining was apostolic and to a large extent also the legacy of the early churches of the apostles and of the church fathers (Trueman 2012:17, 122, 123). They therefore embraced many confessional standards of the early ecumenical councils. Many of the confessional standards that were made during the 16th century reformation even have explicit articles which show that these were the result or fruit of a biblical theological reading of the whole Bible wherein Jesus is the focus of all the Scriptures. One of the most popular of these reformed confessions in Africa is the Heidelberg Catechism. Its Sunday6 discusses Jesus Christ as the only mediator. It then formulates its Question 19 and the accompanying answer as follows (Williamson 1993):

Question 19: Whence do you know this? Answer: From the holy gospel, which God Himself first revealed in Paradise; afterwards published by the holy patriarchs and prophets, and foreshadowed by the sacrifices and the other ceremonies of the law; and lastly fulfilled by His only begotten Son. (p. 31)

The passages listed in support of the answer come from both the Testaments. The following instructive comments by Spykman (1984) on this answer of the Heidelberg Catechism are worth pondering:

Not only from Matthew to Revelation, but also from Genesis to Malachi, Christ is the key that unlocks the meaning of the Bible. Therefore, Christ himself could speak of searching the Scriptures and add that 'it is they that bear witness to me' (Jn 5:39). Christ's work ties all sixty-six books together into one gospel of salvation. His coming, concealed in the Old Testament, is revealed in the New Testament. If in reading the Bible we miss Christ, we miss the point completely. (p. 61)

Statements such as the one found in answer to Question 19 of the Heidelberg Catechism are properly appreciated when they are recognised as the fruit of reading the whole Bible that is composed of books that are diverse and were written at different times in history but still show a unity. The gospels and Acts promote such a reading. Such statements that embody reformed biblical theology can, in turn, further guide towards a proper reading of the Bible when they are not shunned as part of presuppositions that are affirmed when reading the Bible. Silva (2007:88) helpfully indicates that the 'very possibility of understanding anything depends on our prior framework of interpretation'.

\section{Conclusion}

The following are some of the insights that this exploration of how the gospels and Acts relate the reading of the Scriptures by the apostles to Jesus yields:

1. Not only did Jesus suffer and die for sinners, but he also taught and is the source of the witness of the apostles. Their legacy to the church is from Jesus. 
2. Jesus identified himself by all the Scriptures and taught his disciples to understand his person and work by the Scriptures which he taught them to read in a way that they saw him as the focus of all of the Scriptures.

3. Jesus transformed the way the apostles read the Scriptures and through their teaching transformed the reading of the Scriptures by many Jews that believed and were baptised in the name of Jesus and were part of the early church.

4. The authority of the apostles as teachers of the church of Jesus Christ comes from Jesus himself. Their teaching was accorded the same authority that was given to the Scriptures of the Old Testament from the onset in the early church. The books associated with their witness were accordingly read together as one with those of the Old Testament in the early church. These books include the gospels and Acts,

5. The recognition of the oneness of the Old and New Testaments which the apostles bequeathed to the church comes from the way Jesus taught them to read the Scriptures.

6. There was division within the Jewish communities in Judea and throughout the Roman Empire. The majority of the Jews rejected both Jesus and his apostles. Many Gentiles, however, accepted the message of the apostles.

7. A reading of the Bible that affirms the oneness of the Bible books and their character and status as books whose message is centred on Jesus in spite of their diversity arising from their occasional nature and literary forms have been part of the Christian church since Pentecost.

8. The reformed confessions, in as far as in many of their formulations advocate for a reading of the Bible in which Jesus is the focus of all of the Scriptures, should be appreciated as continuing the legacy of Jesus Christ through his apostles, and be allowed to guide Christians when reading the Bible.

\section{Acknowledgements Competing interests}

The author declares that he has no financial or personal relationships that may have inappropriately influenced him in writing this article.

\section{Author's contributions}

T.C.R. is the sole author of this research article.

\section{Ethical considerations}

This article followed all ethical standards for a research without direct contact with human or animal subjects.

\section{Funding information}

This research did not receive any grant from any funding agency in the public, commercial or not-for-profit sectors.

\section{Data availability statement}

Data sharing is not applicable to this article as no new data were created or analysed in this study.

\section{Disclaimer}

The views and opinions expressed in this article are those of the author and do not necessarily reflect the official policy or position of any affiliated agency of the author.

\section{References}

Bauckham, R., 2006, Jesus and the eyewitnesses, Eerdmans, Grand Rapids, MI.

Beale, G.K., 2011, A New Testament biblical theology, Baker Academic, Grand Rapids, MI.

Bimson, J.J., Kane, J.P., Paterson, J.H. \& Wiseman, D.J. (eds.), 1985, New Bible Atlas, InterVarsity Press, Leicester.

Bock, D.I., 2007, Acts, Baker Academic, Grand Rapids, MI.

Boda, M.J., 2012, 'Biblical theology and Old Testament interpretation', in C.H. Bartholomew \& D.J.H. Beldman (eds.), Hearing the Old Testament, pp. 122-153, Eerdmans, Grand Rapids, MI.

Boda, M.J., 2017, The heartbeat of Old Testament theology, Baker Academic, Grand Rapids, MI.

Boring, M.L., 2006, Mark: A commentary, Westminster John Knox Press, Louisville, KY. Cairns, E.E., 1981, Christianity through the centuries, Zondervan, Grand Rapids, MI. Card, M., 2014, John: The gospel of wisdom, Intervarsity Press, Downers Grove, IL. Carroll, J.T., 2012, Luke: A commentary, Westminster John Knox Press, Louisville, KY.

Carson, D.A., 2008, 'Biblical-theological ruminations on Psalm 1', in L.G. Tipton \& J.C. Waddington (eds.), Resurrection and eschatology, pp. 115-134, P \& R Publishing, Phillipsburg, NJ.

Craig, S.G., 1965, Jesus of yesterday and today, Presbyterian and Reformed Publishing Company, Philadelphia, PA.

Cullmann, O., 1963, The Christology of the New Testament, SCM Press, London.

Dempster, S.G., 2012, 'Canon and Old Testament interpretation', in C.H. Barthololomew $\&$ D.J.H. Beldman (eds.), Hearing the Old Testament, pp. 154-179, Eerdmans, Grand Rapids, MI.

Dever, M., 2005, The message of the New Testament, Crossway Books, Wheaton, IL.

DeYoung, K., 2014, Taking God at His Word, Crossway, Wheaton, IL.

Donnelly, E., 2005, Peter: Eyewitness of his Majesty, The Banner of Truth Trust, Edinburgh.

Gaffin, R.B., 2008, "For our sakes also": Christ in the Old Testament in the New Testament', in R.L. Penney (ed.), The Hope fulfilled, pp. 61-81, Phillipsburg, P \& R Publishing, Phillipsburg, NJ.

Geldenhuys, N., 1977, The Gospel of Luke, The New International Commentary on the New Testament, Eerdmans, Grand Rapids, MI.

Hagner, D.A., 2012, The New Testament, a historical and theological introduction, Baker Academic, Grand Rapids, MI.

Heil, J.P., 2015, The Gospel of John: Worship for divine life eternal, Cascade Books, Eugene, OR.

Hendriksen, W., 1973, The Gospel of John, New Testament Commentary, The Banner of Truth Trust, Edinburgh.

Hendriksen, W., 1975, Mark, New Testament Commentary, Baker Book House, Grand Rapids, MI.

Hill, C.E., 2008, 'God's speech in these last days', in L.G. Tipton \& J.C. Waddington (eds.), Resurrection and eschatology, pp. 203-254, P \& R Publishing, Phillipsburg, NJ.

Hughes, R.K., 2014, Acts, Crossway, Wheaton, IL.

Johnson, D.E., 2007, Him we proclaim, P \& R Publishing, Phillipsburg, NJ.

Kaiser, W.C. \& Silva, M., 2007, Introduction to biblical hermeneutics, Zondervan, Grand Rapids, MI.

Keller, T., 2015, Preaching, Hodder \& Stoughton, London.

Lloyd-Jones, M., 2013, Setting our affections upon glory, Crossway Books, Wheaton, IL.

Longman III, T., 2012, 'History and Old Testament interpretation', in C.H. Barthololomew \& D.J.H. Beldman (eds.), Hearing the Old Testament, pp. 96-121, Eerdmans, Grand Rapids, MI.

Morris, L., 1971, The Gospel according to John, The New International Commentary on the New Testament, Eerdmans, Grand Rapids, MI. 
Provan, I., 2012, 'Hearing the historical books', in C.H. Barthololomew \& D.J.H Beldman (eds.), Hearing the Old Testament, pp. 254-276, Eerdmans, Grand Rapids, MI.

Reymond, R.L., 2008, 'Systematic theology and a burning heart', in R.L. Penney (ed.), The hope fulfilled, pp. 153-175, P \& R Publishing, Phillipsburg, NJ.

Ridderbos, H., 1978, Studies in scripture and its authority, Eerdmans, Grand Rapids, MI.

Schreiner, T.R., 2008. New Testament theology, Baker Academic, Grand Rapids, MI.

Selvaggio, A.T., 2010, The seven signs, Reformation Heritage Books, Grand Rapids, MI. Silva, M., 2007, 'The case for Calvinistic hermeneutics', in K.S. Oliphint \& L.G. Tipton (eds.), Revelation and reason, pp. 74-94, P \& R Publishing, Phillipsburg, NJ. Smuts, P.W., 2013, Mark by the book, P \& R Publishing, Phillipsburg, NJ.

Sproul, R.C., 2005, Scripture alone, P \& R Publishing, Phillipsburg, NJ.
Spykman, G.J., 1984, Never on your own, Board of Publications of the CRC, Grand Rapids, MI.

Stein, R.H., 2008, Mark, Baker Academic, Grand Rapids, MI.

Swindoll, C.R., 2016, Searching the scriptures, Tyndale House Publishers, Caro Stream, IL.

Trueman, C.R., 2012, The Credal imperative, Crossway, Wheaton, IL.

VanDerKam, J.C., 2001, An introduction to early Judaism, Eerdmans, Grand Rapids, MI.

Viljoen, F.P., 2011, Matthew's portraits of Jesus, Potchefstroomse Teologiese Publikasies, Potchefstroom.

Waltke, B.K., 2008, 'Psalm 110: An exegetical and canonical approach', in L.G. Tipton \& J.C. Waddington (eds.), Resurrection and eschatology, pp. 60-85, P \& R Publishing, Phillipsburg, NJ.

Williamson, G.I., 1993, The Heidelberg catechism, P \& R Publishing, Phillipsburg, NJ. 